\title{
Environmental management reporting in Polish mining companies in the context of World CSR trends
}

\author{
Paweł Bogacz ${ }^{1}$ and Marcin Migza1,a \\ ${ }^{1}$ AGH University of Science and Technology, Department of Economy and Management in Industry, al. Mickiewicza 30, 30-059 Krakow, \\ Poland
}

\begin{abstract}
CSR is very fast evolving management concept in the whole world. Therefore environmental management development is one of the most important strategic directions for modern enterprises. It is particularly relevant for mining enterprises, because of their impact on the natural environment. The authors aimed to verify if this trend is reflected in polish mining companies actions. Mining companies are obligated to non-financial reporting. In the paper the level of Global Reporting Initiative (GRI) usage in mining companies was considered. GRI is now the most frequently used method of non-financial reporting in the world..
\end{abstract}

\section{Introduction}

All mining activities, both underground and surface mining have a significant, most often a negative impact on the surrounding environment. The changes may affect lithosphere, atmosphere, hydrosphere, pedosphere and biosphere [1].

Environmental is one of the most important sphere of CSR reporting. It is particularly relevant for mining companies, because their impact on the natural environment is in principle significant.

In December 2014Directive on disclosure of non-financial and diversity information by some big companies came into force. Member states should transpose it into national laws within two years. Therefore the first company reports should be published in 2018, regarding the financial year 2017-2018.

The measures established by the Directive will enhance the transparency and accountability of roughly 6000 businesses in the EU. These so-called 'public interest entities' with more than 500 employees will be:

- Obligated to report on environmental, social and employee-related, human rights, anti-corruption and bribery matters;

- Obligated to present their business model, results and hazards of the policies on the above topics, and the diversity policy in management and supervisory bodies;

- Persuaded to use recognized frameworks such as GRI's Sustainability Reporting Guidelines, the United Nations Global Compact (UNGC), the UN Guiding Principles on Business and Human Rights, OECD Guidelines, International Organization for Standardization (ISO) 26000 and the International Labour Organization (ILO) Tripartite Declaration.

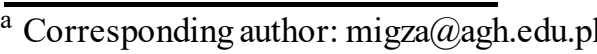

Regarding to this law, mining companies in EU are obligated to non-financial, CSR reporting.

The aim of this article is to verify level of environmental management reporting in Polish mining companies. It focuses particularly on the GRI reporting standards. The observations and conclusions were made from quantitative and qualitative perspective.

\section{Importance of environmental sphere in CSR reporting for mining companies}

CSR is the way in which companies integrate social, environmental and economic matters into their values. It is reflected in companies' culture, strategy, operations and allows to establish better practices within the firm as well as to improve society [2].

According to European Commission CSR is the responsibility of companies for their influence on society. CSR should be company led. Public authorities can play a supporting role.

Companies can follow social responsibility by:

- compliance with the law;

- including social, environmental, ethical, consumer, and human rights matters into the way they run business [3].A sustainability report presents the economic, environmental and social impacts caused by actions of a company. It also shows the organization's values and governance model, and demonstrates how its strategy contributes to a sustainable economy.

Sustainability reporting can be also called as triple bottom line reporting or corporate social responsibility (CSR) reporting. It is also an intrinsic element of integrated reporting; a more recent development that combines the analysis of financial and non-financial performance [4]. 
According to International Council on Mining and Metals survay, environmental concern is one of the most important challenges. Figure 1 presents the most serious issues for the international mining industry, in table 1 . Importance of different kind of areas for the European mining industry was presented.

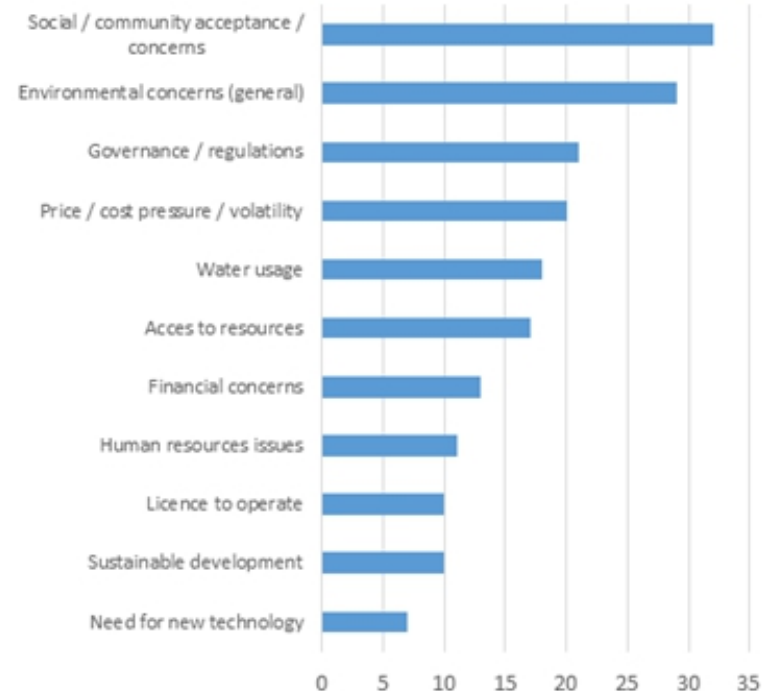

Figure 1. The most serious issues that the international mining industry will face in the next five years [5].

Table 1. Importance of different kind of areas for the European mining industry [5].

\begin{tabular}{|l|c|}
\hline & Europe \\
\hline $\begin{array}{l}\text { Reducing impacts and making improvements } \\
\text { to the environment where possible }\end{array}$ & 91 \\
\hline Improving community relations & 82 \\
\hline Improving its approach to health and safety & 53 \\
\hline $\begin{array}{l}\text { Improving the transparency of paid taxes and } \\
\text { royalties to governments }\end{array}$ & 63 \\
\hline Providing economic benefits and jobs & 55 \\
\hline
\end{tabular}

The environmental aspect of sustainability regards an organization's influence on living and non-living natural systems, including ecosystems, land, air, and water. Environmental Indicators cover performance related to inputs (e.g., material, energy, water) and outputs (e.g., emissions, effluents, waste). Additionally, they cover performance related to biodiversity, environmental compliance, and other important information e.g. environmental expenditure and the impacts of products and services [6].

\section{GRI Environmental Performance Indicators for Mining and Metals Sector}

The GRI (Global Reporting Initiative) guidlines are the most common way of CSR and sustainability reporting. Sustainability reports are released by companies and organizations of all types, sizes and sectors, from every corner of the world.

Thousands of companies across all sectors have published reports that reference GRI's Sustainability Reporting
Guidelines. Public authorities and non-profits are also big reporters. GRI's Sustainability Disclosure Database features all known GRI-based reports [4].

The Global Reporting Initiative (GRI) encourages companies to use the sustainability reporting to become more sustainable. It aims to make sustainability reporting standard practice by sharing free Sustainability Reporting Guidelines. GRI, a not-for-profit, networkbased organization, engages many professionals and organizations of various backgrounds [7].

GRI in cooperation with International Council on Mining and Metals (ICMM) have prepared sustainability reporting guidance for the mining and metals sector. This Supplement has the sector-specific sustainability reporting guidance integrated in the GRI G3 Guidelines, the most widely-used guidelines for reporting on economic, environmental, and social performance. The Supplement covers biodiversity, indigenous rights, labor, community, artisanal and small-scale mining, resettlement, closure planning and materials stewardship [8].

GRI Environmental Performance Indicators for Mining and Metals Sector are presented in table 2.

Table 2. GRI Environmental Performance Indicators for Mining and Metals Sector [6]

\begin{tabular}{|c|c|c|c|}
\hline Aspect & Imp. & No. & Description \\
\hline \multirow{2}{*}{ 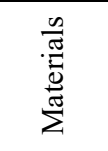 } & Core & EN1 & $\begin{array}{l}\text { Materials used by weight or } \\
\text { volume. }\end{array}$ \\
\hline & Core & EN2 & $\begin{array}{l}\text { Percentage of materials used that } \\
\text { are recycled input materials. }\end{array}$ \\
\hline \multirow{5}{*}{ 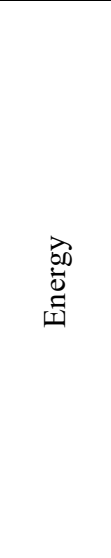 } & Core & EN3 & $\begin{array}{l}\text { Direct energy consumption by } \\
\text { primary energy source. }\end{array}$ \\
\hline & Core & EN4 & $\begin{array}{l}\text { Indirect energy consumption by } \\
\text { primary source. }\end{array}$ \\
\hline & Add & EN5 & $\begin{array}{l}\text { Energy saved due to conservation } \\
\text { and } \\
\text { efficiency improvements. }\end{array}$ \\
\hline & Add & EN6 & $\begin{array}{l}\text { Initiatives to provide energy- } \\
\text { efficientor renewable energy based } \\
\text { productsand services, and } \\
\text { reductions in energyrequirements as } \\
\text { a result of these initiatives. }\end{array}$ \\
\hline & Add & EN7 & $\begin{array}{c}\text { Initiatives to reduce indirect energy } \\
\text { consumption and reductions } \\
\text { achieved. }\end{array}$ \\
\hline \multirow{3}{*}{$\frac{\dot{\Phi}}{\vec{c}}$} & Core & EN8 & Total water withdrawal by source. \\
\hline & Add & EN9 & $\begin{array}{c}\text { Water sources significantly affected } \\
\text { bywithdrawal of water. }\end{array}$ \\
\hline & Add & $\begin{array}{l}\text { EN1 } \\
0\end{array}$ & $\begin{array}{l}\text { Percentage and total volume of } \\
\text { waterrecycled and reused. }\end{array}$ \\
\hline \multirow{2}{*}{ 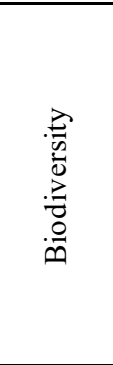 } & Core & $\begin{array}{l}\text { EN1 } \\
1\end{array}$ & $\begin{array}{l}\text { Location and size of land owned, } \\
\text { leased, managed in, or adjacent to, } \\
\text { protected areas and areas of high } \\
\text { biodiversity value outside protected } \\
\text { areas. }\end{array}$ \\
\hline & Core & $\begin{array}{l}\text { EN1 } \\
2\end{array}$ & $\begin{array}{l}\text { Description of significant impacts } \\
\text { of activities, products, and services } \\
\text { on biodiversity in protected areas } \\
\text { and areas of high biodiversity value } \\
\text { outside protected areas. }\end{array}$ \\
\hline
\end{tabular}




\begin{tabular}{|c|c|c|c|}
\hline & Core & $\begin{array}{l}\mathrm{MM} \\
1\end{array}$ & $\begin{array}{l}\text { Amount of land (owned or leased, } \\
\text { and managed for production } \\
\text { activities or extractive use) } \\
\text { disturbed or rehabilitated. }\end{array}$ \\
\hline & Add & $\begin{array}{l}\text { EN1 } \\
3\end{array}$ & Habitats protected or restored. \\
\hline & Add & $\begin{array}{l}\text { EN1 } \\
4\end{array}$ & $\begin{array}{l}\text { Strategies, current actions, and } \\
\text { future plans for managing impacts } \\
\text { on biodiversity. }\end{array}$ \\
\hline & Core & $\begin{array}{l}\mathrm{MM} \\
2\end{array}$ & $\begin{array}{l}\text { The number and percentage of total } \\
\text { sites identified as requiring } \\
\text { biodiversity management plans } \\
\text { according to stated criteria, and the } \\
\text { number (percentage) of those sites } \\
\text { with plans in place. }\end{array}$ \\
\hline & Add & $\begin{array}{l}\text { EN1 } \\
5\end{array}$ & $\begin{array}{l}\text { Number of IUCN Red List species } \\
\text { and national conservation list } \\
\text { species with habitats in areas } \\
\text { affected by operations, by level of } \\
\text { extinction risk. }\end{array}$ \\
\hline \multirow{11}{*}{ 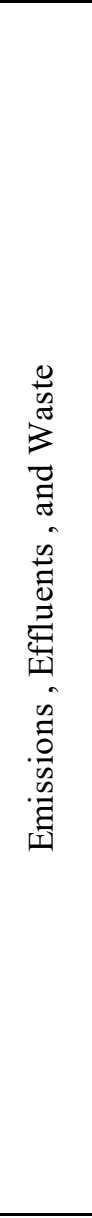 } & Core & $\begin{array}{l}\text { EN1 } \\
6\end{array}$ & $\begin{array}{l}\text { Total direct and indirect greenhouse } \\
\text { gas emissions by weight. }\end{array}$ \\
\hline & Core & $\begin{array}{l}\text { EN1 } \\
7\end{array}$ & $\begin{array}{l}\text { Other relevant indirect greenhouse } \\
\text { gas emissions by weight. }\end{array}$ \\
\hline & Add & $\begin{array}{l}\text { EN1 } \\
8 \\
\end{array}$ & $\begin{array}{l}\text { Initiatives to reduce greenhouse gas } \\
\text { emissions and reductions achieved. }\end{array}$ \\
\hline & Core & $\begin{array}{l}\text { EN1 } \\
9\end{array}$ & $\begin{array}{l}\text { Emissions of ozone-depleting } \\
\text { substances by weight. }\end{array}$ \\
\hline & Core & $\begin{array}{l}\text { EN2 } \\
0\end{array}$ & $\begin{array}{l}\mathrm{NO}, \mathrm{SO} \text {, and other significant air } \\
\text { emissions by type and weight. }\end{array}$ \\
\hline & Core & $\begin{array}{l}\text { EN2 } \\
1\end{array}$ & $\begin{array}{c}\text { Total water discharge by quality } \\
\text { and destination. }\end{array}$ \\
\hline & Core & $\begin{array}{l}\text { EN2 } \\
2\end{array}$ & $\begin{array}{c}\text { Total weight of waste by type and } \\
\text { disposal method. }\end{array}$ \\
\hline & Core & $\begin{array}{l}\mathrm{MM} \\
3\end{array}$ & $\begin{array}{l}\text { Total amounts of overburden, rock, } \\
\text { tailings, and sludges and their } \\
\text { associated risks. }\end{array}$ \\
\hline & Core & $\begin{array}{l}\text { EN2 } \\
3\end{array}$ & $\begin{array}{l}\text { Total number and volume of } \\
\text { significant spills. }\end{array}$ \\
\hline & Add & $\begin{array}{l}\text { EN2 } \\
4\end{array}$ & $\begin{array}{l}\text { Weight of transported, imported, } \\
\text { exported, or treated waste deemed } \\
\text { hazardous under the terms of the } \\
\text { Basel Convention Annex I, II, III, } \\
\text { and VIII, and percentage of } \\
\text { transported waste shipped } \\
\text { internationally. }\end{array}$ \\
\hline & Add & $\begin{array}{l}\text { EN2 } \\
5\end{array}$ & $\begin{array}{l}\text { Identity, size, protected status, and } \\
\text { biodiversity value of water bodies } \\
\text { and related habitats significantly } \\
\text { affected by the reporting } \\
\text { organization's discharges of water } \\
\text { and runoff. }\end{array}$ \\
\hline \multirow{2}{*}{ 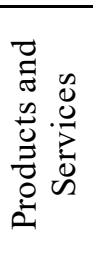 } & Core & $\begin{array}{l}\text { EN2 } \\
6\end{array}$ & $\begin{array}{l}\text { Initiatives to mitigate } \\
\text { environmental impacts of products } \\
\text { and services, and extent of impact } \\
\text { mitigation. }\end{array}$ \\
\hline & Core & $\begin{array}{l}\text { EN2 } \\
7\end{array}$ & $\begin{array}{l}\text { Percentage of products sold and } \\
\text { their packaging materials that are } \\
\text { reclaimed by category. }\end{array}$ \\
\hline 承 & Core & $\begin{array}{l}\text { EN2 } \\
8\end{array}$ & $\begin{array}{l}\text { Monetary value of significant fines } \\
\text { and total number of non-monetary } \\
\text { sanctions for noncompliance with } \\
\text { environmental laws and regulations. }\end{array}$ \\
\hline
\end{tabular}

\begin{tabular}{|c|c|c|c|}
\hline 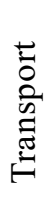 & Add & $\begin{array}{l}\text { EN2 } \\
9\end{array}$ & $\begin{array}{l}\text { Significant environmental impacts } \\
\text { of transporting products and other } \\
\text { goods and materials used for the } \\
\text { organization's operations, and } \\
\text { transporting members of the } \\
\text { workforce. }\end{array}$ \\
\hline 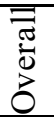 & Add & $\begin{array}{l}\text { EN3 } \\
0\end{array}$ & $\begin{array}{l}\text { Total environmental protection } \\
\text { expenditures and investments by } \\
\text { type. }\end{array}$ \\
\hline
\end{tabular}

\section{Environmental management reporting in polish mining companies}

The most important Polish mining companies were subject to non-financial reporting. Not all of them were able to implement this. Table 3 presents the most important Polish mining companies and their level of CSR reporting.

Table 3. Sustainability reporting in polish mining companies in 31.12.2015

\begin{tabular}{|l|c|c|}
\hline \multicolumn{1}{|c|}{ Company } & $\begin{array}{c}\text { Sustainability } \\
\text { reporting }\end{array}$ & $\begin{array}{c}\text { GRI } \\
\text { Guidelines }\end{array}$ \\
\hline LW Bogdanka S.A. & + & + \\
\hline Famur S.A. & - & - \\
\hline JSW S.A. & + & - \\
\hline $\begin{array}{l}\text { KGHM Polska } \\
\text { Miedź S.A. }\end{array}$ & + & + \\
\hline KHW S.A. & + & + \\
\hline Kopex S.A. & + & + \\
\hline KW S.A. & - & - \\
\hline PG Silesia & + & - \\
\hline PGE S.A. & + & + \\
\hline $\begin{array}{l}\text { Tauron Polska } \\
\text { Energia S.A. }\end{array}$ & - & - \\
\hline Węglokoks S.A. & & - \\
\hline
\end{tabular}

The analysis of Table 3 shows that among the 11 most important Polish mining companies, only 3 have not introduced any sustainability reporting. Companies that have not yet implemented the non-financial reporting are Famur SA, KW SA and Węglokoks SA.

No CSR reporting may be especially surprising in the case of KW SA, which is the largest mining company in Europe, employing over 50000 employees. Mining company with such a powerful impact on the environment and the local community should be particularly committed to a sustainable development.

Among the companies that have implemented CSR reporting, the vast majority (6 of 8 ) has adopted GRI guidelines. This trend is reflected in the whole world where GRI is the most widely used standard.

Table 4 shows in detail the level of reporting the specific areas within environmental reporting of CSR in Polish mining enterprises, using GRI standard. Five areas of CSR reporting, which are described below, are completely missed by all Polish mining companies: EN2, MM2, EN24, EN27, EN29. 
There is only one sphere, which appears in the sustainable reports of all the companies presented in Table 4. This is an EN8 area - Total water withdrawal by source. Among the Polish mining companies declaring reporting environmental sphere according to GRI guidelines KGHM Polska Miedź S.A. copes definitely the best. From 33 detailed areas 25 are reported by this company, two more: EN14 (Strategies, current actions, and future plans for managing impacts on biodiversity) and EN21 (Total water discharge by quality and destination) are reported in an incomplete or inadequate manner.

The areas completely ignored in reports of KGHM are also missed in all other mining companies. These are: EN2, MM2, EN24, EN27, EN29. The exception is EN19 (Emissions of ozone-depleting substances by weight), not reported by KGHM, but which can be found in the report of KHW S.A.

Table 4. Reporting of GRI Environmental Performance Indicators for Mining and Metals Sector in polish mining companies.

\begin{tabular}{|c|c|c|c|c|c|c|c|c|}
\hline Aspect & Imp. & No. & 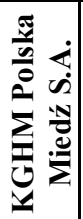 & 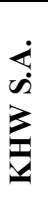 & 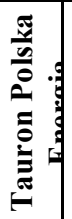 & 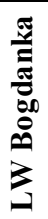 & 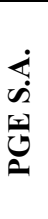 & 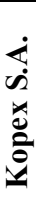 \\
\hline \multirow{2}{*}{ Materials } & Core & EN1 & + & - & + & + & + & - \\
\hline & Core & EN2 & - & - & - & - & - & - \\
\hline \multirow{5}{*}{ Energy } & Core & EN3 & + & - & + & + & + & + \\
\hline & Core & EN4 & + & + & - & + & - & - \\
\hline & Add & EN5 & + & + & + & + & + & - \\
\hline & Add & EN6 & + & - & - & + & - & - \\
\hline & Add & EN7 & + & - & - & - & - & - \\
\hline \multirow{3}{*}{ Water } & Core & EN8 & + & + & + & + & + & + \\
\hline & Add & EN9 & + & - & - & + & - & - \\
\hline & Add & EN10 & + & + & + & + & + & - \\
\hline \multirow{7}{*}{ Biodiversity } & Core & EN11 & + & + & - & + & - & - \\
\hline & Core & EN12 & + & - & + & + & + & - \\
\hline & Core & MM1 & + & - & - & - & - & - \\
\hline & Add & EN13 & + & + & - & + & - & - \\
\hline & Add & EN14 & $+/-$ & - & + & + & + & - \\
\hline & Core & MM2 & - & - & - & - & - & - \\
\hline & Add & EN15 & + & - & - & + & + & + \\
\hline \multirow{11}{*}{$\begin{array}{l}\text { Emissions, } \\
\text { Effluents and } \\
\text { Waste }\end{array}$} & Core & \begin{tabular}{l|} 
EN16 \\
\end{tabular} & + & + & + & + & + & - \\
\hline & Core & EN17 & + & - & - & - & - & - \\
\hline & Add & EN18 & + & + & + & - & + & - \\
\hline & Core & \begin{tabular}{l|l} 
EN19 \\
\end{tabular} & - & + & - & - & - & - \\
\hline & Core & EN20 & + & + & + & + & + & - \\
\hline & Core & EN21 & $+/-$ & + & + & + & + & - \\
\hline & Core & EN22 & + & + & + & + & + & - \\
\hline & Core & MM3 & + & - & - & + & - & - \\
\hline & Core & EN23 & + & - & + & + & + & + \\
\hline & Add & EN24 & - & - & - & - & - & - \\
\hline & Add & EN25 & + & + & + & - & + & - \\
\hline \multirow{2}{*}{$\begin{array}{l}\text { Products and } \\
\text { Services }\end{array}$} & Core & EN26 & + & + & - & + & - & - \\
\hline & Core & EN27 & - & - & - & - & - & - \\
\hline Compliance & Core & EN28 & + & + & + & + & + & - \\
\hline Transport & Add & EN29 & - & - & - & - & - & - \\
\hline Overall & Add & EN30 & + & + & + & - & + & - \\
\hline
\end{tabular}

KHW S.A. reports less than a half ( 16 of 33 ) of areas identified in the GRI guidelines. A similar level of reporting is observed in Tauron Polska Energia (16 areas) and PGE S.A. (17 areas).

These three companies are reporting mostly the same, or similar areas, which suggests that they used common patterns in the process of creating the reports

Reporting at the level of approximately $50 \%$ of the guidelines is far too poor result. But reports of these companies already provide an image of the business activity impact on the environmental sphere.

Slightly wider range is contained in LW Bogdanka SA's report, in which references to 21 of 33 environmental areas indicated in the GRI guidelines can be found.

Definitely the worst was the outcome of Kopex S.A., which report covered only 4 areas: EN3, EN8, EN15 and EN23. At this level it is difficult to speak about CSR reporting or especially about the use of the GRI guidelines, which has been declared by the company. The report is too narrow to draw conclusions based on it regarding the impact of business on the environment.

\section{Summary}

In conjunction with introduction of the duty of non-financial reporting in EU, the most important Polish mining companies have been forced to sustainable reporting. EU authorities left some flexibility in choosing the method of reporting, but the most commonly used standard is the GRI. Similar situation is in the metal and mining industry, for which GRI together with ICMM prepared special guidelines. Also in Poland, among mining companies that have already implemented the CSR reporting, majority declares the use of this standard.

Due to intense impact of mining companies on the environment, the environmental area is the most important one of non-financial reporting for these companies. The authors analyzed in detail the reports of Polish mining companies declaring environmental reporting according to the GRI guidelines. The only company that in a satisfactory manner fulfills the recommendations of this standard is KGHM Polska Miedź S.A. Other audited companies meet approximately $50 \%$ of the requirements in their reports. Definitely the worst is the result of Kopex S.A., which report contains only 4 elements of the GRI guidelines.

Generally, Polish mining companies follow the same path as world companies, but still a considerable part of them have not implemented the non-financial reporting. Those that already fulfill this requirement, still do not do this with reasonable accuracy and commitment. The optimistic phenomenon is the rapid increase in the importance of CSR in Polish mining industry. With the appropriate amount of effort Polish mining companies have a chance to catch up with the world leaders, as exemplified by KGHM Polska Miedź S. A. 


\section{References}

1. Lapcik, V., Lapcikova, M., J. of the Polish Min. Eng. Soc. 12, 1-10, (2011).

2. http://www.iisd.org/pdf/2007/csr_guide.pdf

3. http://ec.europa.eu/corporate-social-responsibility/

4. https://www.globalreporting.org/default.aspx

5. http://www.icmm.com/document/8615

6. Sustainability Reporting Guidelines \& Mining and Metals Sector Supplement. Version 3.0/MMSS Final Version, C2000-2010 GRI

7. GRI G4 Guidelines and ISO 26000:2010 How to use the GRI G4 Guidelines and ISO 26000 in conjunction

8. www.globalreporting.org 